\title{
The Housekeeping Genes GAPDH and Cyclophilin Are Regulated by Metabolic State in the Liver of Dairy Cows ${ }^{1}$
}

\author{
R. P. Rhoads, ${ }^{\star}$ C. McManaman, ${ }^{\star}$ K. L. Ingvartsen,† and Y. R. Boisclair \\ *Department of Animal Science, \\ Cornell University, Ithaca, NY 14853, \\ †Department of Animal Health and Welfare, \\ Danish Institute of Agricultural Sciences, \\ DK-8830 Tjele, Denmark
}

\section{ABSTRACT}

Steady-state levels of mRNA are often used to infer treatment effects on the levels of the corresponding protein. In addition, an internal standard RNA is usually measured to document specificity of treatment and to correct for intersample variation. Our objective was to evaluate whether glyceraldehyde-3-phosphate dehydrogenase (GAPDH) and cyclophilin could be used as internal standards when studying changes in hepatic gene expression in dairy cows. Hepatic expression of GAPDH and cyclophilin was measured in 6 cows in late pregnancy ( $28 \mathrm{~d}$ prepartum) and early lactation (10 d postpartum). Each gene displayed 2- to 3-fold higher expression in early lactation than in late pregnancy. Next, we determined whether negative energy balance alone or in combination with exogenous growth hormone could mimic the effects of early lactation. Latelactating cows were fed $120 \%$ of predicted energy requirements or $33 \%$ of maintenance requirements. During each feeding period, cows were administered excipient or bovine somatotropin in a single-reversal design with 4-d periods separated by a 2 -d interval. Underfeeding increased hepatic expression of GAPDH and cyclophilin by 1 - to 2 -fold, whereas bovine somatotropin had no effect. Finally, the effects of insulin were studied by performing hyperinsulinemic-euglycemic clamps in late pregnancy ( $28 \mathrm{~d}$ prepartum) and early lactation (28 d postpartum). Hyperinsulinemia reduced GAPDH expression in both states, and cyclophilin expression in early lactation. In conclusion, GAPDH and cyclophilin are regulated in the liver of dairy cows and should not be used to standardize hepatic gene expression in studies involving the transition period, undernutrition, and sustained changes in plasma insulin.

Received May 28, 2003.

Accepted July 10, 2003.

Corresponding author: Y. R. Boisclair; e-mail yrb1@cornell.edu.

${ }^{1}$ Supported by the National Research Initiative Competitive Grant Program, USDA CREES 00-35206-9352 (to Y. R. B.) and by the Cornell University Agricultural Experiment Station.
(Key words: housekeeping genes, liver, dairy cow)

Abbreviation key: EB = energy balance, GAPDH = glyceraldehyde-3-phosphate dehydrogenase, $\mathbf{G H}=$ growth hormone, $\mathbf{M E}=$ metabolizable energy, RT-PCR $=$ reverse transcription-PCR.

\section{INTRODUCTION}

In high yielding dairy cows, the transition from pregnancy to lactation is marked by the onset of a sustained period of nutritional insufficiency (Bauman and Currie, 1980; Bell, 1995). Maintenance of homeostasis and well being under these conditions require major shifts in the metabolism of all classes of nutrients. In this context, adaptations occurring in liver are particularly important (Bauman and Currie, 1980; Bell, 1995). This is because liver controls the fate of many absorbed and endogenously produced nutrients, and their supply to the rest of the body (Reynolds et al., 1994; Bergman and Pell, 1999). Defects in the timing or amplitude of hepatic adaptations increase susceptibility of transition dairy cows to disorders such as ketosis and hepatic lipidosis (Goff and Horst, 1997; Drackley, 1999). Periparturient diseases have immediate and long-term negative effects on milk production and on other determinants of profitability such as reproduction (Drackley, 1999; Butler, 2000). These observations have prompted intensive efforts to characterize metabolic events in livers underlying a successful transition period, and to identify defects leading to diseased states.

A growing number of investigators are relying on steady-state levels of mRNA to infer changes in the levels of corresponding hepatic enzymes, receptors, and secreted proteins (Kobayashi et al., 1999; Hartwell et al., 2001; Pershing et al., 2002). Expression of genes is often measured by conventional methods such as northern and ribonuclease protection assays, and increasingly by high throughput methods such as real time quantitative reverse transcription-polymerase chain reaction (RT-PCR, e.g., TaqMan assay). In all of these methods, it is usual to measure at least one 
additional cellular RNA to serve as an internal standard. The internal standard RNA is used to document specificity of treatment effects and to correct for intersample variation. To be a valid internal standard, the selected RNA must be expressed at a constant level across individuals and be unaffected by the treatment under study (Bustin, 2000, 2002).

Our interest in understanding the roles of growth hormone (GH) and IGF-I during the transition period led us to perform measurements of hepatic gene expression (Rhoads et al., 2002). Our first effort was to evaluate the possibility of using glyceraldehyde-3-phosphate dehydrogenase (GAPDH) or cyclophilin as internal standards. We found that expression of both housekeeping genes were dynamically up-regulated in the liver during the transition from pregnancy to lactation and therefore cannot be used as internal standards during that period.

\section{MATERIALS AND METHODS}

\section{Animals and Design}

Experiments were performed on multiparous Holstein cows at Cornell University or at the Danish Institute of Agricultural Science with the guidance and approval of the local institutional or National animal care committee. During lactation, cows were milked twice daily with an 11- to 13-h interval between milking. Protein, fat, and lactose content of milk was determined by infrared analysis (Dairy One Cooperative, Ithaca, NY; Mashek et al., 2001).

Effect of physiological state. There were 6 cows studied in late pregnancy ( $28 \pm 1.5 \mathrm{~d}$ before parturition) and in early lactation ( $10 \pm 1.6$ days postpartum). They were fed a TMR consisting of $1.56 \mathrm{Mcal}$ of $\mathrm{NE}_{\mathrm{L}}$ and 140 $\mathrm{g}$ of CP/kg DM during pregnancy, and $1.59 \mathrm{Mcal}$ of $\mathrm{NE}_{\mathrm{L}}$ and $198 \mathrm{~g}$ of CP/kg DM during lactation (NRC, 1989). Feed was provided ad libitum, in 12 bihourly meals, and water was available at all times. Liver tissue was obtained by percutaneous biopsy using a custom made trocar (Smith et al., 1997).

Plane of nutrition and bST. Six nonpregnant cows were used when averaging $479 \pm 33$ DIM and $19.8 \pm$ $0.7 \mathrm{~kg}$ of $4 \%$ FCM. They were fed a single TMR containing $1.54 \mathrm{Mcal}$ of $\mathrm{NE}_{\mathrm{L}}$ and $157 \mathrm{~g}$ of $\mathrm{CP} / \mathrm{kg} \mathrm{DM}$. Cows were fed amounts corresponding to $120 \%$ of their predicted energy requirements or $33 \%$ of their maintenance requirements for 14 consecutive days. During the last $10 \mathrm{~d}$ of each feeding period, they were used in a single reversal design with 4-d periods separated by a 2 $\mathrm{d}$ interval. Treatments consisted of daily intramuscular injection of saline or $40 \mathrm{mg}$ of bST at $0900 \mathrm{~h}$ (CP104301, lot 96-J-B5128-002, Monsanto Inc., St. Louis, MO). During both periods, the daily feed allowance was distrib- uted into 12 bihourly meals with water available at all times. Liver biopsies were obtained between 1400 and $1500 \mathrm{~h}$ at each feeding level on the fourth day of saline or bST treatment.

Effect of insulin during pregnancy and lactation. Effects of insulin were studied by performing hyperinsulinemic-euglycemic clamps in late pregnancy and early lactation using previously published methods (McGuire et al., 1995; Mashek et al., 2001). Late-pregnant cows were described above (see effect of physiological state). Briefly, after obtaining a liver biopsy $28 \pm$ $1.5 \mathrm{~d}$ before parturition, infusion of purified bovine insulin (lot 615-70N-80; 26.6 IU/mg; Lilly Research Laboratories, Indianapolis, IN) was initiated at the rate of 1 $\mu \mathrm{g} / \mathrm{kg}$ of BW per hour. The concentration of blood glucose was maintained within $10 \%$ of that observed during the basal period (basal blood concentration, $49 \mathrm{mg} /$ dl) by varying the rate of intrajugular infusion of a $50 \%$ dextrose solution (Butler Co., Columbus, $\mathrm{OH}$ ). A second liver biopsy was obtained after $96 \mathrm{~h}$ of insulin infusion.

A second group of 4 cows were studied in wk 4 of lactation (Mashek et al., 2001, 2002). They were fed ad libitum levels of a TMR containing 2.72 Mcal of metabolizable energy (ME)/kg of DM and $18.8 \% \mathrm{CP}$ at 0800 and $1400 \mathrm{~h}$. The experiment consisted of a 4-d period of basal observation followed by a 4-d infusion of bovine insulin $(1 \mu \mathrm{g} / \mathrm{kg}$ of BW per hour, Novo Actrapid Okse, batch no. HL50213; 26.4 IU/mg; Novo Nordisk A/ $\mathrm{S}$, Bagsvaerd, Denmark). During the clamp, the glucose concentration of blood was maintained within $10 \%$ of basal glucose concentrations (basal plasma concentration, $59 \mathrm{mg} / \mathrm{dl}$ ) by varying the rate of infusion of a $50 \%$ glucose solution (Mashek et al., 2001). Percutaneous liver biopsies were taken $48 \mathrm{~h}$ before and $96 \mathrm{~h}$ after initiation of insulin infusion using an automatic biopsy instrument (MARMON/MDTECH, Gainesville, FL) as described by Andersen et al. (2002).

\section{Analysis of Gene Expression}

Total RNA was extracted from liver biopsies by a modification of the guanidinium thiocyanate-phenolchloroform method (Rhoads et al., 2000). The concentration of total RNA was determined by absorbance at 260 $\mathrm{nm}$, and its quality was verified by staining formaldehyde agarose gel with Syber Green II (Molecular Probes, Eugene, OR). Total RNA (10 $\mu \mathrm{g})$ was stained with ethidium bromide and fractionated on agaroseformaldehyde gels. After electrophoresis, gels were photographed, and the abundance of the $28 \mathrm{~S}$ and $18 \mathrm{~S}$ ribosomal bands was quantified by densitometry (Alpha Innotech IS1000 Digital Imaging System, Alpha Innotech Co., San Leandro, CA). Membranes were blotted 


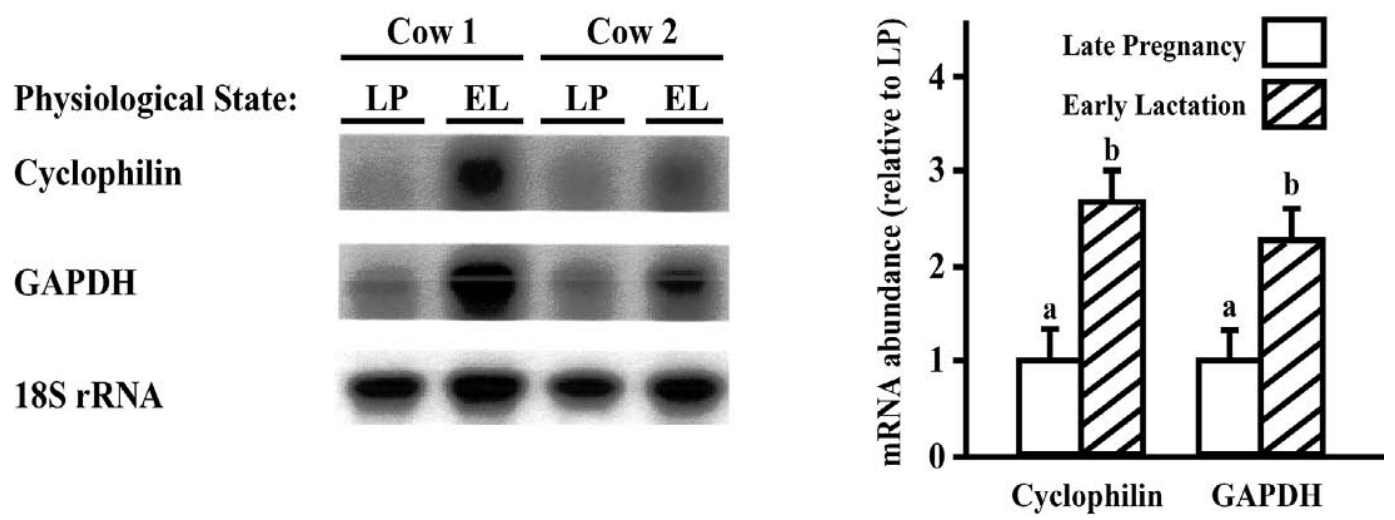

Figure 1. Effects of physiological state on hepatic expression of the genes encoding cyclophilin and GAPDH. Left: Representative northern analysis of total RNA isolated from liver biopsies of two cows in late pregnancy (LP) and early lactation (EL). Each lane represents $10 \mu \mathrm{g}$ of total RNA hybridized to gene-specific probes. Transcripts of approximately 0.75 and $1.4 \mathrm{~kb}$ were detected for cyclophilin and GAPDH, respectively. Each hybridization signal was quantified by phosphoimaging and normalized to the 18S signal. Right: The normalized value for each mRNA signal was analyzed by GLM. A total of 6 animals were used in this analysis. Means \pm SE are expressed relative to the signal obtained for the late-pregnant cows and are shown in graphical form. Bars with different letters differ at $P<0.05$.

onto nylon membranes, and hybridized to gene-specific probes (Rhoads et al., 2000).

The GAPDH probe corresponded to a 556-bp, partial ovine cDNA (Accession \#U94889; Lee et al., 1998). A partial 624-bp cyclophilin DNA fragment was generated from liver total RNA by RT-PCR using a bovine EST sequence previously derived from (Genbank accession \#BF046681). DNA sequencing confirmed identity with bovine cyclophilin (Accession \#AF228021; Dissen et al., 2000).

Probes were labeled with $\left[\alpha-{ }^{32} \mathrm{P}\right] \mathrm{dCTP}(3,000 \mathrm{Ci} /$ mmol) by random priming (Prime-It, Strategene, La Jolla, CA). The 18S ribosomal RNA was detected with a low specificity $\left[\gamma_{-}{ }^{32} \mathrm{P}\right]$ ATP-labeled primer (Deindl, 2001). Hybridizations were conducted with a 10 -fold molar excess of primer over membrane bound 18S RNA. Signals were quantified by phosphoimaging using a Fujix Bio-imaging Analyser BAS 1000 (Fuji Medical Systems, Ltd., Stamford, CT).

\section{Statistical Analyses}

Analyses were performed using the general linear model procedures from the statistical software Minitab (Release 12, State College, PA). For each study, data were analyzed using a mixed model accounting for the treatment as a fixed factor (i.e., physiological state, insulin, or nutrition) and cow as the random factor.

\section{RESULTS}

\section{Effect of Physiological State}

Cows were in positive EB in late pregnancy and in negative EB in early lactation (9.0 vs. $-14.6 \mathrm{Mcal}$ of
$\left.\mathrm{NE}_{\mathrm{L}} / \mathrm{d} ; P<0.001\right)$. All animals had normal delivery and were free of disease after parturition. During lactation, they averaged $43.4 \mathrm{~kg} / \mathrm{d}$ of $4 \%$ FCM during the $3-\mathrm{d}$ period preceding the liver biopsy. Hepatic expression of cyclophilin and GAPDH were 2- to 3 -fold higher in early lactation than in late pregnancy $(P<0.05$; Figure 1). Therefore, both housekeeping genes are induced during the transition from pregnancy to lactation.

\section{Plane of Nutrition and bST}

The development of negative EB during the transition from pregnancy to lactation is associated with a rise in the plasma concentration of GH (Bell, 1995; Block et al., 2001). To determine whether negative EB and elevated GH could mimic the effects of early lactation in the absence of parturition, late-lactation cows were treated with bST when well-fed or underfed. The shift from the high to the low plane of nutrition caused a substantial energy deficit (5 vs. $-13 \mathrm{Mcal}$ of $\mathrm{NE}_{\mathrm{L}} / \mathrm{d}$, well-fed vs. underfed, $P<0.001)$. Underfeeding doubled GAPDH $(P<0.05$; Figure 2$)$ and tended to triple cyclophilin expression $(P=0.073)$. In contrast, bST had no consistent effects on expression of either gene during fed or underfed conditions (results not shown). These data indicate that undernutrition is largely responsible for increased hepatic expression of cyclophilin and GAPDH in early lactation.

\section{Effect of Insulin During Pregnancy and Lactation}

Chronic periods of negative EB such as early lactation and underfeeding are associated with reduced plasma concentration of insulin (Bell, 1995; Block et al., 2001). To examine the role of insulin in regulating GAPDH 

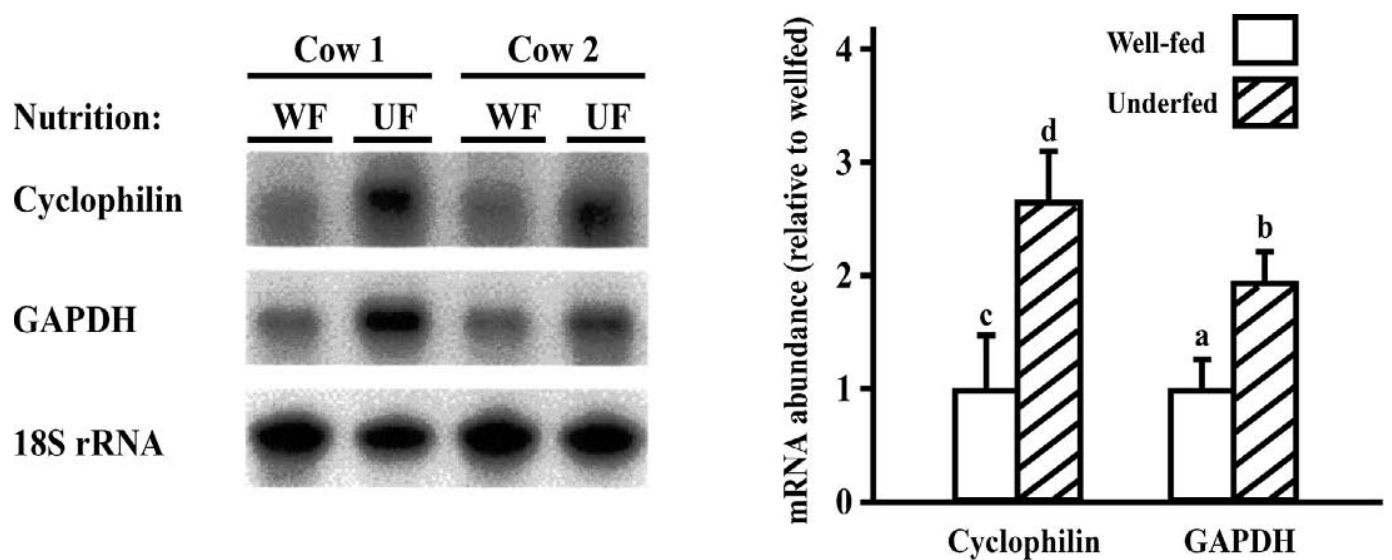

Figure 2. Effects of nutrition on hepatic expression of the genes encoding cyclophilin and GAPDH. Left: Representative northern analysis of total RNA isolated from liver biopsies of two cows that were well-fed (WF) and underfed (UF). Each lane represents $10 \mu \mathrm{g}$ of total RNA hybridized to gene-specific probes. Refer to the legend of Figure 1 for the size of each transcript. Each hybridization signal was quantified by phosphoimaging and normalized to the $18 \mathrm{~S}$ signal. Right: The normalized value for each mRNA signal was analyzed by GLM. A total of 6 animals were used in this analysis. Means $\pm \mathrm{SE}$ are expressed relative to the signal obtained for the well-fed cows and are shown in graphical form. Bars with different letters differ at $P<0.05$ (a,b) or tended to differ at $P=0.073$ (c,d).

and cyclophilin expression, we studied hepatic expression before and after 96 -h periods of hyperinsulinemiaeuglycemia in late pregnancy (28-d prepartum) and early lactation (28-d postpartum). Insulin infusion raised plasma concentration 2 -fold in late pregnancy (1.8 to $4.0 \mathrm{ng} / \mathrm{ml} ; P<0.001)$ and 6 -fold in early lactation (0.22 to $1.48 \mathrm{ng} / \mathrm{ml} ; P<0.001$; Mashek et al., 2001). During both physiological states, exogenous glucose was infused to maintain glycemia within $10 \%$ of basal concentration. Glucose infusion increased the energy surplus during pregnancy $(9.0$ vs. $14.1 \mathrm{Mcal} / \mathrm{d}$; basal vs. clamp; $P<0.05)$ and eliminated the energy deficit of early lactation (-8.5 vs. $1.1 \mathrm{Mcal}$ of $\mathrm{ME} / \mathrm{d}$; basal vs. clamp; $P<0.001$; Mashek et al., 2002). Hyperinsulinemia inhibited the expression of GAPDH gene by $\sim 30$ to $40 \%$ during both physiological states $(P<0.05$; Figure 3 ). Insulin exerted similarly potent inhibitory effects on cyclophilin gene expression during lactation, but not during pregnancy $(P<0.05$; Figure 3$)$. These data suggest that hypoinsulinemia is partly responsible for hepatic induction of GAPDH and cyclophilin expression during periods of nutritional insufficiency.

\section{DISCUSSION}

We restricted our analysis to the GAPDH and cyclophilin genes because of their widespread use as internal RNA standards (Bustin, 2000), including studies of hepatic gene expression in cattle (Kobayashi et al., 1999; Butler et al., 2003). The roles of the corresponding proteins are well understood. GAPDH catalyzes the oxidative phosphorylation of glyceraldehyde-3-phosphate to 1,3-bisphosphoglycerate during glycolysis as well as the reverse reaction in tissues involved in gluconeogenesis. GAPDH has also been implicated in other ubiquitous processes such as DNA replication and repair, and apoptosis (Corbin et al., 2002). Cyclophilin plays a number of roles ranging from molecular chaperone to protein folding (Ivery, 2000). Because of these ubiquitously important functions, transcription of both genes is often assumed to proceed constitutively (Bustin, 2000). Our findings show that this assumption does not hold in bovine liver during the transition from pregnancy to lactation. Others have recently reported similar results in early-lactating dairy cows for neutrophil GAPDH expression (Madsen et al., 2002) and hepatic cyclophilin expression (Radcliff et al., 2002). In addition, we show that induction of each gene was recapitulated in livers of chronically underfed dairy cows, demonstrating that the nutritional insufficiency associated with early lactation contributes significantly to this regulation.

Hyperinsulinemia inhibited GAPDH expression in late-pregnant and early-lactating dairy cows. This effect may reflect improved net EB resulting from the infusion of exogenous glucose, or it could reflect a direct inhibitory effect of insulin. To our knowledge, the bovine GAPDH promoter has not been characterized, but two insulin response elements have been identified in the promoter of the human gene (Nasrin et al., 1990). Moreover, insulin regulates GAPDH expression in the rat liver cell lines H4IIE and H35, the mouse adipocyte cell line 3T3 F442A and in differentiating rat brown adipocytes (Alexander-Bridges et al., 1992; O'Brien and Granner, 1996; Barroso et al., 1999). Therefore, a model whereby insulin directly regulates GAPDH expression, 


\section{Late Pregnancy}
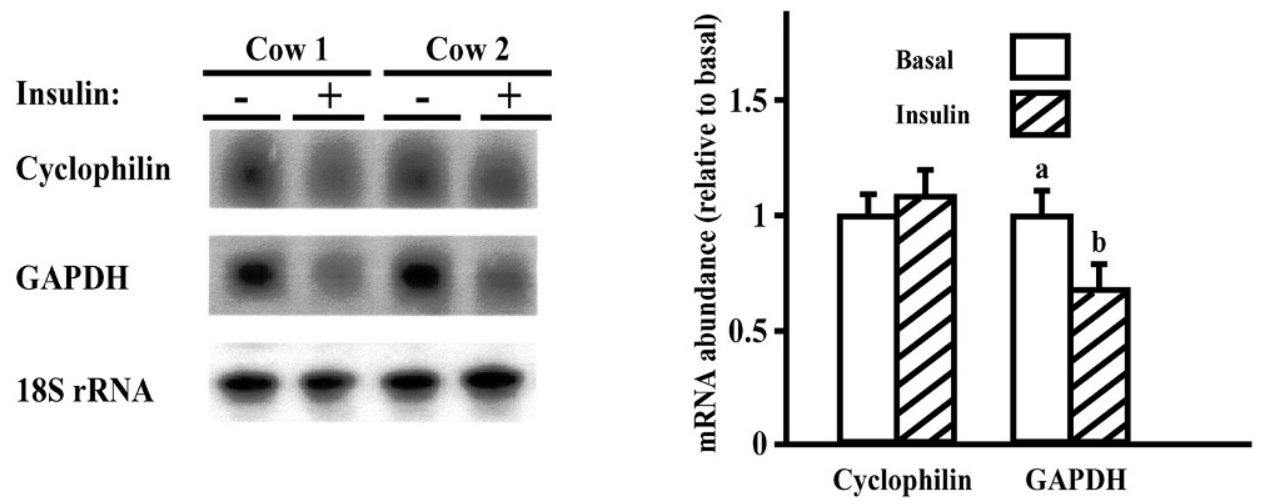

\section{Early Lactation}
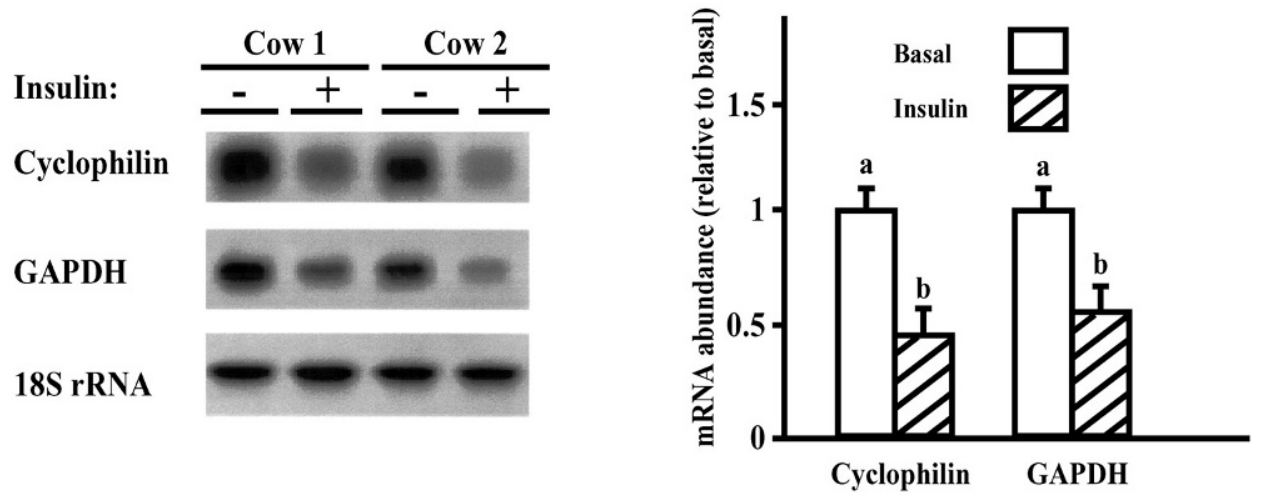

Figure 3. Effects of hyperinsulinemia and physiological state on hepatic expression of the genes encoding cyclophilin and GAPDH. Cows were studied in late pregnancy (top) or during early lactation (bottom). Representative northern analysis of total RNA isolated from liver biopsies of two cows during periods of basal observation (-) and insulin infusion (+). Each lane represents $10 \mu \mathrm{g}$ of total RNA hybridized to gene-specific probes. Refer to the legend of Figure 1 for the size of each transcript. Each hybridization signal was quantified by phosphoimaging and normalized to the $18 \mathrm{~S}$ signal. The normalized value for each mRNA signal was analyzed by GLM. A total of 6 animals were used in late pregnancy and 4 animals were used in early lactation. Means \pm SE are expressed relative to the signal obtained for the basal period and are shown in graphical form on the right of each northern blot panel. Bars with different letters differ at $P<0.05$.

as it does in humans and rodents, is possible in bovine liver.

Insulin also had inhibitory effects on cyclophilin expression in early lactation but not in late pregnancy. Lack of an effect in late pregnancy could relate to limited sensitivity of Northern analysis when basal expression is low. Alternatively, inhibition of cyclophilin expression during the lactating clamp may be mediated by a factor other than insulin, such as alleviation of negative net EB. This model could explain why hepatic cyclophilin expression was inhibited in early lactating cows when exogenous glucose infusion led to positive
$\mathrm{EB}$, but not in late-pregnant cows that were always in positive EB.

Our results have practical implications for the design of gene expression studies. First, GAPDH and cyclophilin should not be used as internal standards when the target tissue is liver and the treatments include severe undernutrition, chronic changes in plasma insulin or the transition from pregnancy to lactation. This conclusion was reached by normalizing the GAPDH and cyclophilin signals to that of the 18S ribosomal RNA. However, the same treatment effects were detected when uncorrected signals or signals corrected for ribo- 
somal RNA abundance (measured by densitometry) were used in the statistical analysis (results not shown). The use of GAPDH and cyclophilin as internal standards is likely valid in liver under other circumstances, but this would need to be verified experimentally. Northern analysis is perhaps the easiest and best method for this purpose. Quality of RNA is easily visualized, and equality of loading can be quantified precisely by staining and/or hybridization detection of the 28 or 18S ribosomal RNA species, as done in this paper. With the growing popularity of real-time RT-PCR, one can anticipate its use to justify whether the use of a specific internal standard RNA is appropriate (Butler et al., 2003). As pointed out by Bustin (2002), the ease and rapidity with which data is acquired by real-time RTPCR can easily create a false sense of objectivity. These assays use small amounts of RNA and, therefore, are more prone to errors due to variation in RNA input (Bustin, 2000). Moreover, without an appropriate internal standard, one has to assume that the enzymatic efficiencies of the reverse transcription and polymerase amplification steps are invariant across samples (Bustin, 2000). Under such conditions, real-time PCR assays should be avoided for the purpose of validating an internal standard RNA, unless the investigator is in a position to perform assays on a large number of treated and untreated samples.

In summary, expression of the GAPDH and cyclophilin genes is induced in the liver during prolonged periods of nutritional insufficiency such as chronic undernutrition and early lactation. Moreover, the insulin deficit characteristic of both states is partly responsible for the induction of cyclophilin and GAPDH mRNA. Therefore, these mRNA cannot serve as internal standards when studying changes in hepatic gene expression caused by undernutrition, the transition from pregnancy to lactation and sustained changes in plasma insulin concentration. Unless another mRNA can be shown to be unaffected by these conditions, it is best to report uncorrected data or to normalize data to ribosomal RNA.

\section{REFERENCES}

Alexander-Bridges, M., I. Dugast, L. Ercolani, X. F. Kong, L. Giere, and N. Nasrin. 1992. Multiple insulin-responsive elements regulate transcription of the GAPDH gene. Adv. Enzyme Regul. 32:149-159

Andersen, J. B., D. G. Mashek, T. Larsen, M. O. Nielsen, and K. L. Ingvartsen. 2002. Effects of hyperinsulinemia under euglycemic condition on liver fat metabolism in dairy cows in early and midlactation. J. Vet. Med. A Physiol. Pathol. Clin. Med. 49: 65-71.

Barroso, I., B. Benito, C. Garci-Jimenez, A. Hernandez, M. J. Obregon, and P. Santisteban. 1999. Norepinephrine, tri-iodothyronine and insulin upregulate glyceraldehyde- 3-phosphate dehydrogenase mRNA during Brown adipocyte differentiation. Eur. J. Endocrinol. 141:169-179.
Bauman, D. E., and W. B. Currie. 1980. Partitioning of nutrients during pregnancy and lactation: A review of mechanisms involving homeostasis and homeorhesis. J. Dairy Sci. 63:1514-1529.

Bell, A. W. 1995. Regulation of organic nutrient metabolism during transition from late pregnancy to early lactation. J. Anim Sci. 73:2804-2819.

Bergman, E. N., and J. M. Pell. 1999. Integration of amino acid metabolism in the ruminant. Pages 613-628 in Herbivore Nutrition in the Subtropics and Tropics. F. M. C. Gilchrist and R. I. Mackie, ed. The Science Press, Craighall, South Africa.

Block, S. S., W. R. Butler, R. A. Ehrhardt, A. W. Bell, M. E. Van Amburgh, and Y. R. Boisclair. 2001. Decreased concentration of plasma leptin in periparturient dairy cows is caused by negative energy balance. J. Endocrinol. 171:339-348.

Bustin, S. A. 2000. Absolute quantification of mRNA using real-time reverse transcription polymerase chain reaction assays. J. Mol. Endocrinol. 25:169-193.

Bustin, S. A. 2002. Quantification of mRNA using real-time reverse transcription PCR (RT-PCR): trends and problems. J. Mol. Endocrinol. 29:23-39.

Butler, S. T., A. L. Marr, S. H. Pelton, R. P. Radcliff, M. C. Lucy, and W. R. Butler. 2003. Insulin restores GH responsiveness during lactation-induced negative energy balance in dairy cattle: effects on expression of IGF-I and GH receptor 1A. J. Endocrinol. 176:205-217.

Butler, W. R. 2000. Nutritional interactions with reproductive performance in dairy cattle. Anim. Reprod. Sci. 60-61:449-57.

Corbin, I. R., Y. Gong, M. Zhang, and G. Y. Minuk. 2002. Proliferative and nutritional dependent regulation of glyceraldehyde-3-phosphate dehydrogenase expression in the rat liver. Cell Prolif. 35: 173-182.

Deindl, E. 2001. 18S ribosomal RNA detection on Northern blot employing a specific oligonucleotide. Biotechniques 31:1250-1252.

Dissen, G. A., J. A. Parrott, M. K. Skinner, D. F. Hill, M. E. Costa, and S. R. Ojeda. 2000. Direct effects of nerve growth factor on thecal cells from antral ovarian follicles. Endocrinology 141:4736-4750.

Drackley, J. K. 1999. Biology of dairy cows during the transition period: The final frontier? J. Dairy Sci. 82:2259-2273.

Goff, J. P., and R. L. Horst. 1997. Physiological changes at parturition and their relationship to metabolic disorders. J. Dairy Sci. 80:1260-1268.

Hartwell, J. R., M. J. Cecava, and S. S. Donkin. 2001. Rumen undegradable protein, rumen-protected choline and mRNA expression for enzymes in gluconeogenesis and ureagenesis in periparturient dairy cows. J. Dairy Sci. 84:490-497.

Ivery, M. T. 2000. Immunophilins: Switched on protein binding domains? Med. Res. Rev. 20:452-484.

Kobayashi, Y., C. K. Boyd, C. J. Bracken, W. R. Lamberson, D. H. Keisler, and M. C. Lucy. 1999. Reduced growth hormone receptor (GHR) messenger ribonucleic acid in liver of periparturient cattle is caused by a specific down-regulation of GHR 1A that is associated with decreased insulin-like growth factor I. Endocrinology 140:3947-3954.

Lee, G. H., M. L. Thonney, and H. M. Richards. 1998. Partial clone and sequence of an ovine glyceraldehyde-3-phosphate dehydrogenase cDNA. J. Anim. Sci. 76:917.

Madsen, S. A., S. D. Weber, and J. L. Burton. 2002. Altered expression of cellular genes in neutrophils of periparturient dairy cows. Vet. Immunol. Immunopathol. 86:159-175.

Mashek, D. G., K. L. Ingvartsen, J. B. Andersen, M. Vestergaard, and T. Larsen. 2001. Effects of a four-day hyperinsulinemic-euglycemic clamp in early and mid-lactation dairy cows on plasma concentrations of metabolites, hormones, and binding proteins. Domest. Anim. Endocrinol. 21:169-185.

Mashek, D. G., L. R. Norup, J. B. Andersen, and K. L. Ingvartsen. 2002. Effects of 4-day hyperinsulinemic-euglycemic clamps during early and mid-lactation on milk yield, milk composition, feed intake, and energy balance. Livest. Prod. Sci. 77:241-251.

McGuire, M. A., D. A. Dwyer, R. J. Harrell, and D. E. Bauman. 1995. Insulin regulates circulating insulin-like growth factors and some 
of their binding proteins in lactating cows. Am. J. Physiol. 269:E723-E730.

Nasrin, N., L. Ercolani, M. Denaro, X. F. Kong, I. Kang, and M. Alexander. 1990. An insulin response element in the glyceraldehyde-3-phosphate dehydrogenase gene binds a nuclear protein induced by insulin in cultured cells and by nutritional manipulations in vivo. Proc. Natl. Acad. Sci. 87:5273-527.

National Research Council. 1989. Nutrient Requirements of Dairy Cattle. 6th rev. ed. Natl. Acad. Sci., Washington, DC.

O'Brien, R. M., and D. K. Granner. 1996. Regulation of gene expression by insulin. Physiol. Rev. 76:1109-1161.

Pershing, R. A., S. D. Moore, A. C. Dinges, W. W. Thatcher, and L. Badinga. 2002. Short communication: Hepatic gene expression for gluconeogenic enzymes in lactating dairy cows treated with bovine somatotropin. J. Dairy Sci. 85:504-506.

Radcliff, R. P., B. L. McCormack, and M. C. Lucy. 2002. Expression of growth hormone receptor (GHR) 1A, IGF-I, total GHR and cyclophilin (cyclo) mRNA in hepatic tissue of periparturient Holstein cows. J. Dairy Sci. 85(Suppl. 1):349. (Abstr.)

Reynolds, C. K., D. L. Harmon, and M. J. Cecava. 1994. Absorption and delivery of nutrients for milk protein synthesis by portaldrained viscera. J. Dairy Sci. 77:2787-2808.

Rhoads, R. P., P. L. Greenwood, A. W. Bell, and Y. R. Boisclair. 2000. Organization and regulation of the gene encoding the sheep acidlabile subunit of the 150-kilodalton insulin-like growth factorbinding protein complex. Endocrinology 141:1425-1433.

Rhoads, R. P., B. J. Leury, L. H. Baumgard, S. S. Block, D. A. Dwyer, A. W. Bell, D. E. Bauman, and Y. R. Boisclair. 2002. Effect of insulin on the GH-IGF-I axis in the periparturient dairy cow. J. Dairy Sci. 85(Suppl. 1):195. (Abstr.)

Smith, T. R., A. R. Hippen, D. C. Beitz, and J. W. Young. 1997. Metabolic characteristics of induced ketosis in normal and obese dairy cows. J. Dairy Sci. 80:1569-1581. 